\author{
PAWEŁ IZDEBSKI ${ }^{1}$ \\ Wydział Pedagogiki i Psychologii \\ Uniwersytet Kazimierza Wielkiego w Bydgoszczy
}

Studia Psychologica

UKSW

16(1) 2016 s. $35-45$

\title{
METODY PSYCHOLOGII DZIECKA I ICH PRAKTYCZNE ZASTOSOWANIA W ODRODZONEJ POLSCE W UJĘCIU ANIELI SZYCÓWNY
}

\begin{abstract}
STRESZCZENIE
Celem tego krótkiego artykułu jest przedstawienie twórczości Anieli Szycówny, wybitnej badaczki psychiki dzieciecej. Zostaną w nim opisane wykorzystywane przez nią metody psychologii dziecka oraz ich praktyczne zastosowania. Szycówna należy do pionierów polskiej psychologii rozwojowej i pedagogiki empirycznej, opartej na badaniach rozwoju dziecka. Jej zainteresowanie problematyką rozwoju dziecka i wychowania oraz pracą nauczyciela zaowocowało znaczącym dorobkiem, wpływającym na sposób myślenia całego pokolenia nauczycieli pracujących w odrodzonej Polsce.
\end{abstract}

Słowa kluczowe: metody psychologii dziecka, praktyczne zastosowania, historia psychologii, Aniela Szycówna

\section{METhODS OF CHILD PSYCHOLOGY AND THEIR PRACTICAL APPLICATIONS in Reborn Poland in Aniela Szycówna's view}

\begin{abstract}
The purpose of this short article is to present the works of Aniela Szycówna, an outstanding researcher of children's minds. The article describes methods used by her and their practical applications. Szycówna is one of the pioneers of Polish developmental psychology and empirical pedagogy based on the research in children's development. Her interests in the problems of child development, education and the work of teachers led to significant research attainments, which influenced the way of thinking of the whole generation of teachers working in reborn Poland.
\end{abstract}

Keywords: methods of child psychology, practical applications, history of psychology, Aniela Szycówna

$1 \quad$ Adres do korespondencji: pawel@ukw.edu.pl. 


\section{WPROWADZENIE}

An dieser Stelle ist es für mich eine angenehme Pflicht, im besonderen herzlichst zu danken: Fräulein ANIELA SZYC, der Vorsitzenden der polnischen Gesellschaft für Kinderforschung in Warschau, deren Empfehlung mir den Zutritt zu verschiedenen Schulen gewährte (da die betreffenden Direktoren mit der Durchführung nicht einverstanden waren...) (Baumgarten, 1917, s. 15)2.

To jedno zdanie, pochodzące z pracy Franciszki Baumgarten, pokazuje znaczenie dokonań Anieli Szycówny na początku XX wieku. Składane podziękowanie świadczy o uznaniu dla jej dorobku. Już w naszych czasach, recenzując wydaną w 2012 roku książkę Jana Wnuka na temat literaury naukowej o dzieciach w okresie międzywojennym, Maria Kielar-Turska (2013) pisze: „Szkoda, że prace innych autorów, takich jak Aniela Szycówna, Stefan Szuman, zostały jedynie wymienione" (s. 108). Dlatego dla wypełnienia tej istotnej luki w historii polskiej psychologii swój artykuł poświęcam Anieli Szycównie. Przedstawię dorobek tej wybitnej badaczki psychiki dzieciecej. Opiszę wykorzystywane przez nią metody psychologii dziecka oraz ich praktyczne zastosowania.

\section{ŻYCIE ORAZ DZIALALNOŚĆ PEDAGOGICZNA I SPOEECZNA ANieli Szycówny}

Aniela Szycówna ${ }^{3}$ urodziła się 31 lipca 1869 roku w Warszawie. Naukę rozpoczęła w wieku sześciu lat, na pensji Heleny Budzińskiej. Po zakończeniu początkowej edukacji przez trzy lata pracowała pod kierunkiem nauczycielki i literatki Sokołowskiej. Praca ta miała ją przygotować do egzaminu nauczycielskiego, który zdała w roku 1886. Później kształciła się samodzielnie. Była słuchaczką Uniwersytetu Latającego (tu zetknęła się po raz pierwszy z Janem Władysławem Dawidem), uczestniczyła też w tajnych kursach dokształcających. Po uzyskaniu dyplomu nauczycielskiego przez pewien czas pracowała bezpłatnie

2 „W tym miejscu chcę także spełnić miły obowiązek, bardzo serdecznie dziękując pannie Anieli Szyc, Przewodniczącej Polskiego Towarzystwa Badań nad Dziećmi w Warszawie, za to, że dzięki jej poleceniom uzyskałam dostęp do wielu szkół (których dyrektorzy najpierw nie godzili się na przeprowadzenie moich badań)" (przekł. W. Zeidler). Tekst niemiecki jest odmienny niż późniejsze o 10 lat polskie tłumaczenie samej autorki. W pracy polskiej Baumgarten pisze: „Polecenie p. Anieli Szycównej ułatwiło mi dostęp do niektórych szkół, których przełożeni nie zgadzali się początkowo na przeprowadzenie tych badań. Jej [...] zawdzięczam przeprowadzenie ankiet bez wielkich przeszkód” (1927, s. 23). Porównując oba fragmenty, można zauważyć, że w tekście polskim brakuje wzmianki o funkcji Anieli Szycówny w Polskim Towarzystwie Badań nad Dziećmi.

3 Życiorys Anieli Szycówny opracowałem na podstawie notki biograficznej, której autorką jest Małgorzata Stawiak-Ososińska (2007), oraz Słownika Psychologów Polskich (Kosnarewicz, Rzepa, Stachowski, 1992). 
na wspomnianej pensji Budzińskiej, utrzymując się w tym czasie z prywatnych korepetycji.

W połowie lat 80. XIX wieku Aniela Szyc zaczęła się starać o stałą posadę na żeńskiej pensji, nie otrzymała jednak zezwolenia władz carskich. Ponownie zajęła się więc udzielaniem lekcji prywatnych. W latach 90. rozpoczęła działalność $\mathrm{w}$ różnych instytucjach oświatowych i nawiązała współpracę z redakcjami pism pedagogicznych. Brała udział w kongresach pedagogicznych (m.in. w I Kongresie Pedagogicznym we Lwowie w 1909 roku), zjazdach psychiatrów, pedagogów, nauczycieli praktyków i lekarzy. Była reprezentantką Polski na zjazdach zagranicznych, m.in. na III Światowym Kongresie Higieny Szkolnej w Paryżu w 1910 roku.

Działalność we wspomnianych instytucjach oświatowych rozpoczęła od prowadzenia wykładów na tajnych kursach dla nauczycieli seminariów nauczycielskich. Następnie była aktywnym członkiem Wydziału Wychowawczego Warszawskiego Towarzystwa Higienicznego. Wygłosiła wiele referatów popularyzujących higienę szkolną, wychowanie fizyczne i sport wśród różnych warstw społecznych, organizowała wystawy higieniczne, popularyzowała dorobek Wydziału Wychowawczego WTH w licznych publikacjach na łamach „Zdrowia”. Opracowała projekt organizacji zabaw dziecięcych.

Była najbliższą współpracownicą J.W. Dawida, który włączył ją do prowadzonych przez siebie badań zespołowych. Wraz z nim pracowała nad zasobami pojęć dzieci według „,kwestionariusza spostrzeżeń”. W późniejszym okresie wyniki tej pracy posłużyły jej za wzór do badań własnych. Na początku XX wieku zaczęła starania o założenie w Polsce instytucji, której celem miało być prowadzenie prac badawczych nad dziećmi. Została inicjatorką powołania Polskiego Towarzystwa Badań nad Dziećmi i jego przewodniczącą (1907-1921). W ramach Towarzystwa prowadzono badania psychologiczno-pedagogiczne dotyczące rozwoju umysłowego i fizycznego dzieci, popularyzowano wiedzę pedagogiczną wśród nauczycieli, wydawano kwestionariusze i wskazówki do badań nad dziećmi oraz publikowano wyniki pomiarów i obserwacji prowadzonych przez członków Towarzystwa.

W czasie I wojny światowej Aniela Szycówna uczestniczyła w pracach Wydziału Oświecenia Komitetu Obywatelskiego miasta Warszawy. Weszła w skład Komisji utworzonej przez Związek Nauczycielski, zajmującej się organizowaniem kursów dla nauczycieli. Współpracowała z Biurem Szkolnym (agendą Naczelnego Komitetu Narodowego) przy organizowaniu jednolitej, wysoko zorganizowanej szkoły powszechnej. Współpracowała z Komisją Kursów Wakacyjnych, a od 1916 roku - z Towarzystwem Kursów Naukowych. Pracowała w powołanym do życia w roku 1916 Instytucie Pedagogicznym, a od 1919 kierowała katedrą pedagogiki i powadziła wykłady w Wolnej Wszechnicy Polskiej. Zmarła 26 lutego 1921 roku w Warszawie i została pochowana na Powązkach. 


\section{NAJWAŻNieJSZE PRACE}

Wśród najważniejszych prac Szycówny znajdują się opracowania naukowe i metodologiczne: Rozwój pojęciowy dziecka w okresie 6-12 lat (1899) oraz O zadaniach i metodach psychologii dziecka (1901). Badaczka zajmowała się również metodyką nauczania. Jest autorką m.in. prac: Nauka w domu. Przewodnik dla wychowawców (1895), Gramatyka polska dla dzieci zaczynających się uczyć systematycznie z przykładami, ćwiczeniami i wskazówkami dla nauczycieli, Czytanki stopniowane dla dzieci zaczynających naukę systematyczną. Stopień I. W domu i w szkole, Stopień II. Na wsi i w mieście, Stopień III. W kraju i na świecie (1906), Metodyka wypracowań (1919), Zadania nauki języka polskiego w szkole ludowej (1906).

Swoje poglądy na temat pracy nauczyciela pionierka pedagogiki empirycznej zawarła w dwóch pracach: O powinnościach nauczyciela i jego kształceniu (1915) i w Pedagogice (wykładach na Wolnej Wszechnicy Polskiej) (1916). Podsumowanie jej poglądów na temat wychowania i metod badań dzieci stanowi podręcznik Pedologia, czyli nauka o dziecku (1910). Pierwszym pismem, z którym rozpoczęła współpracę, był „Przegląd Pedagogiczny” (1890). Szycówna była też redaktorką ilustrowanego czasopisma dla dzieci „Moje Pisemko. Tygodnik obrazkowy dla dzieci do lat 10" (1902-1905). W latach 1906-1909 pisała do miesięcznika dla nauczycieli „Nowe Tory”. W roku 1920 została mianowana przez Ministerstwo Wyznań Religijnych i Oświecenia Publicznego redaktorką „Szkoły Powszechnej". Poza czasopismami polskimi publikowała również w amerykańskim czasopiśmie „Pedagogical Seminary”, założonym przez Stanleya Halla.

\section{METODY BADAWCZE W PSYCHOLOGII DZIECKA}

Współpraca z J.W. Dawidem pozwoliła Anieli Szycównie na wykorzystanie opracowanego przez niego Kwestyonaryusza pojęć i poglądów ${ }^{4}$. W pracy Rozwój pojęciowy dziecka w okresie 6-12 lat badaczka przedstawia wyniki, które są uzupełnieniem pracy Dawida Zasób pojęciowy dzieci (1895). O ile Dawid wykazał, „jakie doświadczenia i postrzeżenia ze świata otaczającego posiada dziecko w okresie nauki elementarnej”, o tyle jej praca miała na celu pokazanie, „jakie pojęcia umysł dziecka wytwarza na podstawie tego zasobu" (Szycówna, 1899, s. 6).

W Rozwoju pojęciowym dziecka... widać, że dla Szycówny ilość i jakość pojęć stanowią miarę rozwoju umysłowego. Dlatego zmodyfikowany przez nią jedynie w kilku punktach Kwestyonariusz... Dawida jest stosowną metodą oceny rozwoju pojęć. Składa się on z 56 pytań, które pozwalają na ocenę zasobu pojęciowego z różnych sfer funkcjonowania poznawczego (od „znajomości”

4 Więcej na temat badań J.W. Dawida pisze Ryszard Stachowski. Zob. Stachowski, R. (2011). Pierwszy polski kwestionariusz psychologiczny. W: W. Zeidler (red.), Kwestionariusze w psychologii. Postępy, zastosowania, problemy (s. 139-160). Warszawa: VIZJA PRESS \& IT. 
części ciała, kształtów, stopni pokrewieństwa, ciał niebieskich i zjawisk przyrody do pojęć religijnych, etycznych oraz z dziedziny geografii i historii). Grupę badaną stanowiło 500 dzieci od sześciu do 12 lat (220 chłopców i 280 dziewcząt). Do „klasy niezamożnej” należało 439, a z rodzin „inteligentnych, średnio zamożnych" pochodziło 61. Ocena pochodzenia była dokonywana na podstawie oceny poziomu umysłowego rodziców oraz ich „stopy zamożności”, a także najbliższego otoczenia dziecka.

W kolejnych rozdziałach pracy autorka przedstawia wyniki badania, analizuje różnice między chłopcami i dziewczętami, „inteligentnymi i mało rozwiniętymi”, warszawskimi, amerykańskimi i niemieckimi na podstawie wybranych pytań kwestionariusza, które były wykorzystywane w badaniach amerykańskich i niemieckich i były takie same jak w badaniach polskich. Następnie przedstawia podobieństwa i różnice wśród rodzeństwa. Opisuje też zasób pojęciowy dzieci w badanych obszarach tematycznych. W ostatnim rozdziale badaczka podsumowuje, że „można wyróżnić różne typy umysłowości, wskazujące, jak zdolności dziecka się różniczkują i jak często wzrost jednej okupuje się zanikiem drugiej". Wyodrębnia w rezultacie dwa typy: umysł receptywny (łatwo przyswajający i przechowujący wiadomości odnoszące się do rzeczy konkretnych) i umysł refleksyjny (słabiej przyswajający wiadomości, ale zdolny do wydawania sądów samodzielnych, „wyrażający” własne poglądy). Zauważa też, że różnice indywidualne mają istotne znaczenie w praktyce wychowawczej i w nauczaniu.

Kolejną pozycją ważną dla rozwoju psychologii dziecka w Polsce jest opracowanie, które można nazwać podręcznikiem metodologii: O zadaniach $i$ metodach psychologii dziecka (Szyc, 1901). W rozdziale drugim znajdujemy tam opis metod badania, które były znane Szycównie. Autorka omawia metody: biograficzne - opierające się na systematycznej obserwacji (dziennik dziecka), laboratoryjne (doświadczalne), statystyczne (kwestionariuszowe) i metody porównawcze („zestawienie prac różnych autorów, uzupełnionych przez dokumenty z życia dziecięcego"; s. 17). Stwierdza, że wszystkie metody mają swoją rację bytu, a ich zastosowanie zależy od natury przedmiotu badania. Zauważa też, że szczególnie korzystne jest łączenie metod, np. statystycznej i eksperymentalnej.

Bardzo wartościowy jest opis metody doświadczalnej. Autorka zwraca uwage na zachowanie „dokładności” przy przeprowadzaniu próby, w obliczaniu i notowaniu wyników oraz wyciąganiu wniosków i przypomina, że metoda ta ma zastosowanie „dla takich tylko warunków, w jakich były czynione” (Szyc, 1901, s. 11). Przy opisie metod statystycznych (kwestionariuszowych) zwraca uwage na „dobrą stylizacyję pytań, polegającą na tem, iżby każda z osób odpowiadających, wiedziała o co chodzi i nie miała wątpliwości w tym względzie" (s. 18). Zauważa, że pytania nie powinny być zbyt ogólnikowe, sugestywne i powinny być jasne dla osoby, która ma na nie odpowiadać. Podkreśla wagę dostosowania się do instrukcji badania. 
W dalszej części Szycówna przedstawia stan badań nad dzieckiem oraz podaje przykłady kwestionariuszy (m. in. kwestionariusz Dawida Zasób doświadczeń i wyobraźni, Zasób pojęć i poglądów - kwestionariusz dla dzieci starszych i młodzieży dorastającej, Powiastki do rozwinięcia - dla dzieci od ośmiu do 15 lat). Do każdej metody podane są bardzo szczegółowe wskazówki dla prowadzących badanie (w tym miejscu można podkreślić staranność autorki, która zapewnia poprawność metodologiczną prowadzonych badań). Pracę kończy bibliografia psychologii dziecięcej.

Sposób oceny rozwoju dziecka powyżej czwartego roku życia możemy poznać w pierwszym przykładzie, zatytułowanym bardzo ogólnie: Charakterystyka dziecka. Zawiera on najistotniejsze pytania dotyczące danych socjodemograficznych (określonych jako „szczegóły osobiste”: wiek, płeć, pochodzenie), stan fizyczny oraz pytania dotyczące rozwoju umysłowego dziecka (spostrzegawczość, pamięć, uczenie się - „zdolności naśladowcze”, wyobraźnia i twórczość, rozumowanie, zainteresowania - „zamiłowania umysłowe”, uczucia i ich objawy, zalety i wady dziecka, dziedziczność i otoczenie (ocena wpływu środowiska rodzinnego). Jak pisze Szycówna, metoda ta „przeznaczona jest zarówno dla tych, którzy zechcą dać obraz dziecka w danej chwili, jak i dla tych, którzy zechcą prowadzić jego dziennik przez czas dłuższy” (Szyc, 1901, s. 42).

Ostatnią pracą Szycówny przedstawiającą jej poglądy na temat metod badań, jest wydana po raz pierwszy w roku 1901 książka zatytułowana Jak badać umyst dziecka? (O zadaniach i metodach psychologii dziecka) $)^{5}$. Opracowanie to ma na celu opisanie metod badania dzieci w sposób dostępny dla wszystkich czytelników. Oprócz podziału i opisu metod oraz przykładów kwestionariuszy (zaprezentowanych już w pracy opisanej tu wcześniej) Szycówna omawia dorobek naukowców zajmujących się umysłowością dziecka (badania niemieckie: Bernard Hartmann i Ludwig Strümpell, francuskie: Bernard Perez, angielskie: Karol Darwin, James Sully i Franciszek Warner, włoskie: Vitale Vitali, amerykańskie: Stanley Hall oraz polskie: przede wszystkim prace Jana Władysława Dawida).

Przedstawione publikacje ujawniają świadomość metodologiczną autorki. Jej własne doświadczenie badawcze oraz studia nad literaturą światową utworzyły podstawy metodologiczne, które są bardzo bliskie współczesnym standardom badania dzieci. Szycówna omawia najistotniejsze problemy, które mogą wystąpić podczas tworzenia i wykorzystywania kwestionariuszy. Metoda jest dla niej środkiem pozwalającym na poznanie umysłowości dziecka.

5 Autor artykułu dotarł do wydania z 1904 roku, które, jak pisze Szycówna, jest reedycją wydania z 1901 roku. 


\section{Praktyczne zastosowania}

Oprócz pracy badawczej Szycówna interesowała się wykorzystaniem praktycznym wyników swoich dociekań naukowych. Już w 1906 roku opublikowała książkę zatytułowaną Zadania nauki języka polskiego w szkole ludowej. Jest to przewodnik metodyczny, w którym badaczka opisuje program nauczania języka ojczystego dla dzieci od siedmiu do 14 lat. Program ten miał na celu rozwinięcie po sześciu latach nauki następujących „uzdolnień”: poprawnej mowy - wyrażania się zgodnie z zasadami języka polskiego, rozumienia przeczytanych treści, zamiłowania do czytania literatury pięknej, wyrażania swych myśli „na piśmie”, tj. pisania ortograficznie, poprawnie, jasno i logicznie.

W przewodniku Szycówna zauważa, że „zgodnie z naturalnym porządkiem rozwoju zaczynać należy od poznawania mowy potocznej, a potem dopiero przejść do języka książkowego; pierwej ćwiczyć w ustnym wypowiadaniu myśli, a potym - w piśmiennym" (1906, s. 7). Obserwuje też, że dzieci rozpoczynające naukę często nie znają zbyt wielu pojęć dotyczących najbliższego otoczenia, a niektóre z pojęć są dla nich niejasne i nieścisłe. Używają też błędnych form gramatycznych. Dlatego Szycówna proponuje taki program nauczania, który ma na celu osiągnięcie wymienionych wcześniej umiejętności. Język polski został dopuszczony do szkół na terenie zaboru rosyjskiego w roku 1905. Zadania nauki..., wydane w roku kolejnym, miały duże znaczenie dla kształtowania narodowej tożsamości nie tylko dzieci ze szkoły ludowej.

Zainteresowania społeczne Szycówna realizuje w badaniu kwestionariuszowym (pięć pytań) poświęconym sytuacji polskich matek. W opracowaniu zatytułowanym Kobieta $w$ pedagogice. Matka (Szycówna, 1908) analizuje wyniki badania. Listowne odpowiedzi 89 matek analizuje jakościowo. Opracowanie to traktuje jako „przyczynek do sprawy”.

Bardzo ważną pracę w dorobku pionierki psychologii rozwojowej stanowiła Pedologia. W jej pierwszym rozdziale Szycówna pisze, że „wyraz p e d o l o g i a stanowi najogólniejszą nazwę wszystkich studyów, dotyczących stopniowego rozwoju dziecka, zarówno pod względem fizycznym, jak psychicznym, prowadzonych bądź to niezależnie w celach naukowych, bądź z zastosowaniem do praktyki” (1910, s. 3). Autorka opisuje tu historię badań nad rozwojem dziecka. Jak zauważa, pierwsze badania systematyczne stopniowego rozwoju dziecka nastąpiły się w XVIII wieku. W roku 1787 Dietrich Tiedemann wydał spisane przez siebie obserwacje poczynione w ciągu pierwszych lat życia swojego syna. Szycówna stwierdza, że jest on dlatego w Niemczech nazywany ojcem psychologii dziecięcej. Wśród znaczących postaci wymienia Aurore Necker de Saussure, która była autorką dzieła o wychowaniu i dowodziła, że nauka o dziecku powinna być oparta na systematycznych spostrzeżeniach rodziców i wychowawców. Badaczka wspomina też o Darwinie i Preyerze oraz o osiągnięciach Stanleya Halla w Stanach Zjednoczonych. W roku 1894 Oskar Chrisman nazwał naukę o dziecku pedologią. Gdy w roku 1910 polska autorka wydała 
Pedologię, stwierdziła w niej, że w ciągu tych kilkunastu lat, które upłynęły od nazwania tej dziedziny, badania nad dziećmi rozwinęły się już nie tylko w Stanach Zjednoczonych, lecz także bardzo dynamicznie w Europie.

Opisując zadania nauki o dziecku i jej zakres, Szycówna stwierdza, że ta gałąź badań obejmuje cały okres rozwoju człowieka, od urodzenia aż do osiągnięcia dojrzałości. Wymienia następujące zadania pedologii: badania nad dziećmi rozwijającymi się prawidłowo, porównanie normalnego rozwoju dziecka z jego zboczeniami, zboczenia indywidualne i typy umysłowości, różnice indywidualne zależne od wpływów dziedziczności i otoczenia, określenie wpływu różnych metod i środków wychowania i nauczania ${ }^{6}$.

Na początku pracy O powinnościach nauczyciela i jego kształceniu, wydanej w 1915 roku, znajduje się zamieszczony poniżej cytat:

Jest tyle sit w narodzie,

Jest tyle, mnogo ludzi;

Niechże w nie Duch Twój wstąpi

I śpiace niech obudzi!

St. Wyspiański

Pierwsza wojna światowa już się rozpoczęła. Polacy przygotowują się do odzyskania niepodległości. Niektórzy walczą, a inni, tak jak nasza badaczka, piórem czynią przygotowania, które mają umożliwić funkcjonowanie polskiej szkoły. Szycówna pisze: „Wśród licznych potrzeb, które najsilniej odczuwamy w dzisiejszej przełomowej chwili w życiu narodu, na pierwszym miejscu stoi przyszła szkoła polska. Kiedy zaś zapytają: czego trzeba do wzniesienia dobrej szkoły polskiej? - odpowiemy bez wahania: dwóch tylko warunków: wolności i ludzi $(1915$, s. 3). Praca ta stanowi przełomową (biorąc pod uwagę moment jej napisania) propozycję, w której autorka sformułowała bardzo nowatorskie założenia kształcenia nauczycieli.

Już w pierwszym rozdziale Szycówna zauważa, że nie można dzielić wychowania i nauczania - wychowanie to przygotowanie do życia, a nauczanie stanowi część pracy wychowawczej. Zwraca uwagę na powinności nauczyciela, który powinien być dobrym człowiekiem oraz dobrym pedagogiem: „Nauczyciel samodzielny, a taki tylko powinien nauczać $\mathrm{w}$ dobrej szkole, musi umieć materiał naukowy przystosować do uczniów, których uczy i do warunków, w których naucza” (1915, s. 10). Powinien „posiadać znajomość nauki o nauczaniu, tj. dydaktyki" (s. 15). Autorka sądzi, że nauczyciel powinien znać cele kształcenia i organizację szkoły, ogólne zasady nauczania, oparte na psychologii i podstawach logiki (metodologii nauk), metodykę wykładanego przedmiotu. Nauczyciel powinien „rozwijać w sobie d a r ob se r wa c y i trafnej i szybkiej” (s. 22).

6 Terminy użyte w tekście są oryginalnymi określeniami używanymi przez autorkę (Szycówna, 1910, s. 12). 
Szczególnie ważna, ze względu na czas wydania pracy, jest część poświęcona obowiązkom nauczyciela jako obywatela kraju. Szycówna zastanawia się w niej, w jaki sposób przekazywać dzieciom uczucia patriotyczne, jak im mówić o Polsce i jej sprawach. Pisze, że w każdej nauce zaczynamy od pojęć zasadniczych i dlatego uczniowie powinni najpierw poznać „to co każdy Polak kocha i czcią otacza, co dla każdego Polaka stanowi troskę serdeczną, a nawet ból serdeczny" (1915, s. 29). Dopiero potem można wkraczać w zagadnienia „podrzędne”. Zadaniem szkoły jest kształcenie obywateli kraju, a nie członków partii politycznych. Tak, przy tym te wszystkie uwagi zostały zapisane, kiedy nadszedł czas formułowania na nowo poczucia narodowej świadomości i tożsamości. To chyba - jak by powiedział Wundt - tędy właśnie wiodła droga do kształtowania państwowości. Tej nowej, niezależnej od zaborczego knuta.

$\mathrm{W}$ Metodyce wypracowań, podręczniku wydanym w pierwszym roku niepodległości Polski, Szycówna wykorzystuje swoje badania na temat myślenia pojęciowego dzieci. Opisuje zadania szkoły: „Szkoła, która kształci przyszłych obywateli kraju, winna ich jak najlepiej przygotować do życia i jego zadań. Umiejętność wypowiadania swych myśli ustnie i pisemnie nie jest już dziś wyłącznie udziałem pewnych zawodów specjalnych" (1919, s. 4). Badaczka formułuje kilka zadań, które są związane z pisaniem wypracowań. Dzięki tej umiejętności następuje ćwiczenie zdolności logicznego myślenia, kształcenie wyobraźni i popędu twórczego, pogłębienie znajomości języka oraz wyrobienie łatwości i biegłości w wypowiadaniu myśli na piśmie.

$\mathrm{W}$ dalszej części tej samej pracy znajduje się rozdział poświęcony różnicom indywidualnym. Szycówna proponuje w nim typologię zdolności pisarskich. Zamieszcza klasyfikację rozwoju zdolności pisarskiej, opracowaną na podstawie 2000 wypracowań zebranych przez Polskie Towarzystwo Badań nad Dziećmi. Wyróżnia więc cztery typy: opisowy, opowiadający, refleksyjny oraz uczuciowy. W każdym typie wyodrębnia także podtypy. Dla typu opisowego są to: typ opisowy wyliczający, spostrzegawczy i obrazowy, dla opowiadającego: kronikarski, obrazowy i dramatyczny, dla refleksyjnego: obiektywny i subiektywny, a dla uczuciowego: o swoich indywidualnych stanach oraz wewnętrzny.

Ten praktyczny poradnik stanowił z pewnością źródło inspiracji dla nauczycieli języka ojczystego w odradzającej się Polsce. Szycówna odwołuje się w nim do badań naukowych na temat rozumienia pojęć, które sama wcześniej prowadziła. Główne zadanie wychowawcze upatruje w rozbudzaniu w uczących się większej samodzielności w myśleniu i w działaniu przez wspólną pracę pod kierunkiem nauczyciela. Kluczem do sukcesu w wychowaniu jest dobra znajomość ucznia, która jest możliwa dzięki wykorzystaniu wiedzy naukowej. 


\section{Podsumowanie}

Aniela Szycówna należy do pionierów polskiej psychologii rozwojowej i pedagogiki empirycznej, opartej na badaniach rozwoju dziecka. Jej zainteresowanie problematyką rozwoju dziecka, wychowania i pracą nauczyciela zaowocowało znaczącym dorobkiem wpływającym na sposób myślenia całego pokolenia nauczycieli pracujących w odrodzonej Polsce. Wspomniane na wstępie podziękowanie Franciszki Baumgarten ujawnia jeszcze i to, że niezależnie od własnych zainteresowań i badań, jako przewodnicząca Towarzystwa, Szycówna wspomagała także inicjatywy i zainteresowania innych badaczy, wiedząc, że w tym czasie wystarczy pracy dla wszystkich chętnych.

Potrafiła pracować nad ważnymi problemami, zanim można było o nich pisać. Uprawiała naukę zgodnie z zasadami naukowej metodologii, ale także z uwzględnieniem potrzeb patriotycznych: odbudowy narodowej tożsamości i tworzenia nowej państwowości. Mimo braku formalnego wykształcenia uniwersyteckiego i dysproporcji między otrzymanym oficjalnym wykształceniem a późniejszymi osiągnięciami naukowymi zajmowała się najistotniejszymi problemami edukacyjnymi dla przyszłej Polski. Cała jej wieloletnia działalność badawcza nie była finansowana przez ministerstwo, prowadzona była tylko z funduszy własnych Polskiego Towarzystwa Badań nad Dziećmi - grupy członków wspierających (Sprawozdanie, 1908).

W jednym z listów do Kazimierza Twardowskiego Szycówna pisze: „Wielki idealista w teorii, w działaniu nadzwyczaj powolny i ociężały, nie odczuwa tak silnie potrzeby zastosowania teorii do praktyki, do życia; gdy ja przeciwnie widzę we wszystkim, że tak wiele do roboty, a tak mało ludzi do działania, że grzechem byłoby się usunąć od jakiejkolwiek pracy pożytecznej dla społeczeństwa; dla mnie zaś usunięcie takie byłoby fatalniejsze niż dla kogokolwiek, gdyż z chwilą, gdybym wyraźnie uczuła, że nikomu nie jestem potrzebna, życie straciłoby dla mnie wszelką radość i czułabym się bardzo nieszczęśliwą" (list z z 30 grudnia 1902 roku; Jadczak, 1992, s. 64).

W zakończeniu Sprawozdania... Szycówna pisze: „pragnęliśmy pamiętać sami i innym przypominać, że jak pierwsza myśl o utworzeniu takiej instytucji połączyła we wspólnej idei Polaków z pod różnych zaborów, tak urzeczywistnienie tej myśli musi jednoczyć wszystkich, pragnących pracować dla dobra dziecka polskiego i chwały nauki polskiej" (1908, s. 14). U Szycówny, a także $\mathrm{w}$ tym warszawskim pozytywizmie, rzeczą ważną było poznawanie dziecka wychodzącego ze zniewolenia w okresie zaborów.

Pamiętajmy, że w 1866 roku 10 guberni Królestwa Polskiego włączono bezpośrednio do Cesarstwa Rosyjskiego, w 1867 zakazano używania języka polskiego $\mathrm{w}$ administracji i szkolnictwie. Na ziemiach polskich pod zaborem rosyjskim rewolucja 1905 roku przyniosła szereg pozytywnych zmian. Zaczęto tworzyć polskie instytucje i organizacje społeczne. Taką formę działania umożliwiało wspomniane Polskie Towarzystwo Badań nad Dziećmi. Do polskich szkół 
powrócił język polski. Szycówna była jedną z osób, które stworzyły podstawy metodologiczne i organizacyjne dla późniejszych badań nad dziećmi w Polsce międzywojennej. Rozumiała swoje zadania rzeczywiście praktycznie - jako tworzenie podstaw potrzebnych do budowania świadomości narodowej.

\section{Bibliografia}

Baumgarten, F. (1917). Die Lüge bei Kindern und Jugendlichen. Leipzig: Verlag J. A. Barth.

Baumgarten, F. (1927). Kłamstwo dzieci i młodzieży. Warszawa: „Nasza Księgarnia" Spółki Akc. Związku Nauczycielstwa Szkół Powszechnych. Jadczak, R. (1992). Trzy listy Anieli Szycówny do Kazimierza Twardowskiego. Kultura i Edukacja, 1, 61-69.

Kielar-Turska, M. (2013). Recenzja: Jan Wnęk, 2012, Dziecko w polskiej literaturze naukowej 1918-1939. Warszawa: Oficyna Wydawnicza Aspra - JR. Psychologia Rozwojowa, 18(1), 105-118.

Kosnarewicz, E., Rzepa, T., Stachowski, R. (1992). Słownik Psychologów Polskich. Poznań: Instytut Psychologii UAM.

Sprawozdanie Polskiego T-wa badań nad dziećmi za rok pierwszy 1907. (1908). Pobrane z http://rcin.org.pl/Content/31427/WA004_35081_T3098_Polskietowarzystwo-.pdf

Stawiak-Ososińska, M. (2007). Szycówna Aniela. W: T. Pilch (red.), Encyklopedia Pedagogiczna XXI wieku, Tom VI (s. 379-382). Warszawa: Wydawnictwo Akademickie Żak.

Szyc, A. (1899). Rozwój pojęciowy dziecka w okresie 6-12 lat. Badania nad dziećmi. Warszawa: Skład Główny w Księgarni Wendego i Spółki.

Szycówna, A. (1901). O zadaniach i metodach psychologii dziecka. Lwów: Nakładem Autorki. Związkowa Drukarnia we Lwowie.

Szycówna, A. (1904). Jak badać umysł dziecka? (O zadaniach i metodach pychologii dziecka). Warszawa: Nakładem i Drukiem M. Arcta.

Szycówna, A. (1906). Zadania nauki języka polskiego w szkole ludowej. Warszawa: Księgarnia Naukowa.

Szycówna, A. (1908). Kobieta w pedagogice. Matka. Warszawa: Skład Główny w Księgarni Gebethnera i Wolffa.

Szycówna, A. (1910). Pedologia, czyli nauka o dziecku. Warszawa: Tłocznia Wł. Łazarskiego.

Szycówna, A. (1915). O powinnościach nauczyciela i jego kształceniu. Warszawa: Księgarnia J. Lisowskiej.

Szycówna, A. (1919). Metodyka wypracowań. Warszawa: J. Lisowska. 